\title{
The effect of different processing methods on the nutrient and anti-nutrient composition of African Breadfruit (Treculia Africana)
}

\author{
Obiakor- Okeke P. N., Nnadi Chimdinma C. \\ Faculty of Health Sciences, Department of Nutrition and Dietetics, Imo State University, PMB 2000, Owerri, Imo State Nigeria
}

Email address:

ngoziobiakor2001@yahoo.com (Obiakor- Okeke P. N.), chimdinmannadi@yahoo.com (Nnadi C. C.)

\section{To cite this article:}

Obiakor- Okeke P. N., Nnadi Chimdinma C.. The Effect of Different Processing Methods on the Nutrient and Anti-Nutrient Composition of African Breadfruit (Treculia Africana). International Journal of Nutrition and Food Sciences. Vol. 3, No. 4, 2014, pp. 333-339.

doi: $10.11648 /$ j.ijnfs.20140304.25

\begin{abstract}
Aim: The study was designed to evaluate the effect of different processing methods on the nutrient and antinutrient composition of African Breadfruit (Treculia africana). Methodology: African breadfruit (Treculia africana) was processed by cooking and roasting. Nutrient, antinutrient and sensory evaluation of both the raw, cooked and roasted samples was estimated using the standard assay methods. The samples were analysed with descriptive statistics using SPSS version 14 to determine the percentages (\%), mean, standard deviation (SD) and Least square deviation (LSD). Result: The results showed that protein content ranged from $3.45 \%$ to $23.52 \%$, fat ranged from $1.95-13.90 \%$, carbohydrate (CHO) ranged from $58.70 \%$ to $80.65 \%$, ash ranged from $0.35 \%$ to $10.90 \%$ and fiber ranged from $0.32 \%$ to $8.26 \%$ and The antinutrients; phytate and tannin were absent in roasted and cooked samples but present in the raw samples. The minerals Iron ranged from 1.10-2.05mg/100g, Zinc ranged from $3.15-10.00 \mathrm{mg} / 100 \mathrm{~g}$, Phosphorus ranged from $13.25-42.00 \mathrm{mg} / 100 \mathrm{~g}$ and Potassium ranged from $6.90-21.70 \mathrm{mg} / 100 \mathrm{~g}$. The sensory evaluation showed that breadfruit food products were acceptable in terms of colour flavour, texture and general acceptability. Colour most acceptable in sample A (roasted breadfruit) and least acceptable in sample $\mathrm{B}_{1} / \mathrm{B}_{2}$ (the cooked breadfruit and the water sieved from it). Flavour was most acceptable in sample $A$, texture shows that sample $C$ was most acceptable by the panelist while sample $B_{1} / B_{2}$ was least acceptable. General acceptability shows that sample $C$ was most generally acceptable by the panelists while sample $B_{1} / B_{2}$ was the least acceptable. However, there was no significant difference $(P>0.05)$ in the colour, flavour, texture and general acceptability of the samples. Conclusion: The study showed that preparation of breadfruit dishes by roasting and cooking improved its nutrient composition, eliminated the two antinutrients tannins and phytates analysed in this study and hence the nutrients in breadfruit is better accessed when processed by cooking or roasting and gave acceptable products.
\end{abstract}

Keywords: Effect, Processing Methods, Nutrient, Anti-Nutrient, African Breadfruit

\section{Introduction}

There is increased awareness of the importance of legumes in the diet of Nigerian populace. The main contribution of legumes to the diet of Nigerians is based on their nutritional values, especially their contribution of proteins. African bread fruit (Treculia africana) is one of mankind's important source of nutrients such as vitaminutes, carbohydrates, minerals, proteins and fat. African breadfruit is very important indigenous fruit which generally play a vital role in the diet of $\operatorname{man}^{(1)}$.

African breadfruit (Treculia africana) is a monoecious evergreen fruit belonging to the family of moraceae. It is a widely grown and nutritious tree fruit which is used as vegetable crop. It contains about fifty species of tree that grow in the hot moist region of the southeast Asian tropics. Seed production of African bread fruit is considerable; a nature tree produces up to 30 fruits annually, each fruit yielding $5-10 \mathrm{~kg}$ of seed after processing. In the Northern hemisphere, fructifications is usually at its maximum in July - August but continues throughout the years ${ }^{(2)}$.

The fruit are processed by stacking them in a heap and allowed to ferment. The fermented mass is macerated and washed in running water until all adhering slimy, jellylike substances are removed. African breadfruit is native to tropic African and some other countries in West Indies ${ }^{(2)}$. 
It bears fertile fruit covered in prickly diamond shaped protuberances. The fruit contains black or brown seeds that can be peeled twice and cooked like chestnut ${ }^{(2)}$. The seeds of bread fruit are rich in protein, fat, carbohydrate, and vitaminutes and eaten in many part of African ${ }^{(3)}$. African breadfruit is a grain legume which is currently being considered as several sources of nutrient. It contributes immensely to the diet of Nigerians ${ }^{(4)}$. The seed resemble the groundnut in flavour and uses and it may be processed into flour apart from being cooked and eaten as a main dish (5). The raw seed as well as the edible cotyledon are obtained after parboiling and dehulling.

It has been shown that African breadfruit contains some essential amino acids (EAA) in human diet. However it requires sulphur containing amino acid (cystine, methionine) to produce a desirable pattern of EAA ${ }^{(2)}$. Research findings reported that African breadfruit (Treculia africana) contains $17.23 \%$ protein and $10.27 \%$ oil which makes the seed an oil seed ${ }^{(6)}$. The raw seeds do not store for very long time due to infections by certain rot fungi which includes: Aspergillus niger, Botryodiplodia theobromea and Rhizopus stolonifer. Even the cotyledons obtained after parboiling and dehulling do not keep for up to 12 hours at room temperature ${ }^{(5)}$.

African breadfruit 'Ukwa' in Igbo Language is mostly consumed in Igboland and other parts of the southern states of Nigerian. During festive seasons the rural homes use it as complementary foods to replace expensive foods. In Igboland and elsewhere, "Ukwa" is a free legume that produces fruits. The fruits are hung on the stem and branches and take about four months- to mature. Breadfruit seeds are used to prepare various traditional dishes. They could be roasted, consumed with soups, pound boiled or mashed to make pottage. Breadfruit is much more cherished and utilized in Igbo speaking part of Nigerian and other south east state. In other parts of Nigerian, the crop is not widely cherished due to ignorance of its nutritional potentials, processing preparation and utilization (7).

A major constraint in the utilization of African breadfruit is the difficult dehulling involved in the manual removal of the hulls from the parboilded seeds. This method is quite laborious, time consuming and does not favour effective utilization of the fruit. Another constraint is the long cooking time. Such long cooking time and high temperature can result to loss of flavour and nutrients ${ }^{(7)}$.

Roasting and cooking are high temperature heat treatments of foods. All the major food processing treatment in current use, heat processing is the most encountered and it has a very important effect on various food components and quality. Depending on such factors as time, temperature, moisture content, presence or absence of reducing or oxidizing agents and. other ingredients such as acid, salt, sugars, fat, and other chemicals, heat treatment may have either beneficial or detrimental effects. Thus heat treatment on food must be carefully controlled to avoid or minimized damage to nutritive value, functionality, and sensory properties which determine acceptability.

The aim of this study is to determine the effect of cooking and roasting on the nutrient and antinutrient content of African breadfruit and to evaluate the organoleptic attributes of the dishes and snacks from African breadfruit.

The result of the study would be of value to consumers because it will create general awareness of the nutritional potentials of African breadfruit (Treculia africana) and the effects of the different processing methods. Also, the results would enable government to implement its policy on agriculture by harnessing the cultural practices of massive production of local foods which will in turn reduce the incidence of malnutrition in the society. African breadfruit being a continental dish mostly consumed within the southern part of the country. However, the awareness of the nutritional potentials of the African breadfruit will promote the consumption of other parts of the country' more especially the Northern part.

\section{Materials and Methods}

\subsection{Source of Raw Materials}

The seeds of African breadfruit (Treculia africana) and the Maize (Zea mays) were purchased from Relief market in Owerri Municpla L.G.A, Imo State.

\subsection{Preparation of Different Breadfruit Dishes}

The breadfruit seeds were divided into five portions. The First sample was roasted, the second sample was cooked alone, the third sample was cooked with corn, the fourth sample was dehulled, dried and milled which was used as a control and the fifth sample was milled undehulled.

\subsubsection{Sample 1}

The first sample: $150 \mathrm{~g}$ of the seeds was sorted, washed and roasted traditionally in a frying pan with $1 / 2$ tea spoon salt added to it. It was continuously stirred as it was roasted for about 25 minutes after which it was immediately brought down from the fire and was allowed to cool. It was dehulled after cooling and wrapped air tight with polyethylene bag until needed for analysis.

\subsubsection{Sample 2}

The second samples was sorted, washed and parboiled for about 15 minutes and dehulled. $200 \mathrm{~g}$ of the dehulled breadfruit was weighed out, washed and cooked alone. It was allowed to boil in water for about 1 hour, which after little potash (Akawu) was added into water and the water sieved into the boiling breadfruit. A little while after the potash was added, $1 / 2$ tea spoon of salt was added. It continued boiling for about 45 minutes more and immediately the water was separated. Both the separated water and the residual breadfruit were scooped differently into plastic plates and allowed to cool. After cooling they were covered and kept in the refrigerator until it was needed for analysis. 


\subsubsection{Sample 3}

The third sample: $150 \mathrm{~g}$ of the already dehulled sample was weighed out washed and boiled in water for about 1 hour, which after potash (Akawu) was added in water and the water sieved into the boiling bread fruit. Immediately $50 \mathrm{~g}$ of dried overnight cooked maize was added, 10 minutes later, 1 tea spoon of salt, $1 / 2$ cube of magi, and 1 table spoon of red oil was added. It continued cooking for 35 minute more and stirred very well. It was scooped into a plastic plate and allowed to cool. After cooling, it was covered and kept in the refrigerator until it was needed for analysis.

\subsubsection{Sample 4}

The fourth sample was sorted, washed, parboiled for $15 \mathrm{~min}$ and dehulled. It was sundried for about 4 days, and milled to obtain breadfruit flour. The flour sample was packaged airtight with polyethylene bag until it was needed for analysis. This is represented by the flow chart below:
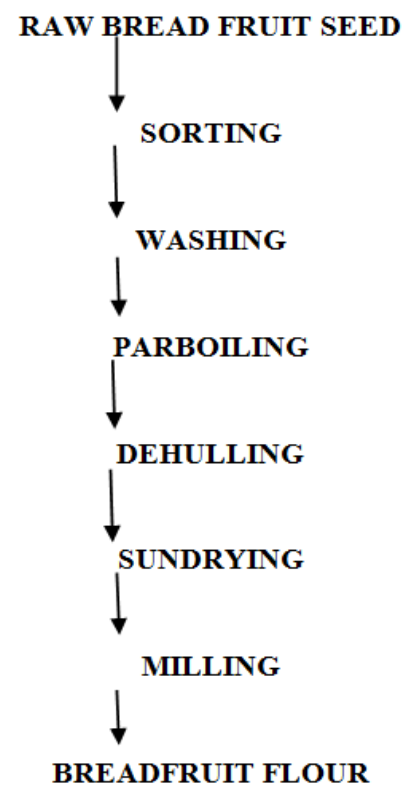

\subsubsection{Sample 5}

The fifth sample was sorted, washed air dried and milled with the hulls.

\subsection{Proximate Analysis}

\subsubsection{Determination of Protein}

Digestion: Protein content was determined using microKjeldahl method of AOAC ${ }^{(8)}$. About $1 \mathrm{~g}$ of each sample was weighed into a $100 \mathrm{ml}$ micro-Kjeldahl digestion flask. About $1 \mathrm{~g}$ of copper sulphate and $10 \mathrm{~g}$ sodium sulphate were added to the flask and thoroughly shaken and placed on the digestion rack in an inclined position. The sample in the flask was digested by heating in a flame chamber until frothing ceased. The temperature was increased, allowed to boil for about one hour until the colour changed to bluish green. The clear digested sample was allowed to cool.

Distillation: Some distilled water was added to the digested sample with a wash bottle to $100 \mathrm{ml}$ in a $100 \mathrm{ml}$ volume metric flask. A- $10 \mathrm{ml}$ of the digest was pipette and transferred into a micro-Kjeldahl distillation flask followed by the addition of $60 \mathrm{ml}$ of $60 \%$ sodium hydroxide $(\mathrm{NaOH})$ solution. The flask was immediately fixed to the splash head of the distillation apparatus. A-4\% boric acid was added into a $100 \mathrm{ml}$ receiving conical flask, 2 drops of methyl red indicator was added, in such a way that the outlet of the adopter of the delivery tube was extended under the surface of the boric acid solution. The mixture was heated to liberate ammonia into the receiving conical flask containing $100 \mathrm{ml}$ boric acid and the indicator until yellowish green colour distillate was obtained.

Titration: The distillate was titrated with $0.1 \mathrm{~N}$ hydrochloric acid $(\mathrm{HCl})$ until the end point of pink colouration was obtained. The percentage (\%) protein was calculated as follows:

$$
\text { Protein }(\%)=\frac{\mathrm{T} \times 0.0014 \times 6.25}{\text { Wt of the sample }} \times \frac{100}{1}
$$

Where $\mathrm{T}=$ titre value of the sample

$0.0014=$ correction factor of the acid

\subsubsection{Determination of Fat AOAC Method ${ }^{(8)}$}

Soxhlet system HT2 method was adapted. The sample was ground and dried and $2 \mathrm{~g}$ were loaded in thimble and plugged with cotton wool. The thimble was dried and inserted into the Soxhlet HT. Extraction cups were dried and weighed (with boiling chips) and $25 \mathrm{ml}$ of the solvent was added into each cup. The cup was inserted into the soxhlet HT and extracted for 15 minutes in boiling position and for 30minutes in "rinsing position". The solvent was evaporated; the cups were released and dried at $100^{\circ} \mathrm{C}$ for 30 minutes. The cups were cooled in a dessicator and reweighed.

$$
\% \text { fat } / \text { oil }=\frac{W_{3}-W_{2}}{W_{1}} \times \frac{100}{1}
$$

Where $\mathrm{W}_{3}=$ weight of the cup with the extraction oil; $\mathrm{W}_{2}=$ weight of the empty cup; $6.25=$ protein conversion factor; $\mathrm{W}_{1}=$ Weight of the sample

\subsubsection{Carbohydrate Determination}

This was determined by difference method. The summation of all the proximate values was subtracted from 100\%. Thus:

$\%$ carbohydrate $=100 \%-(\%$ crude protein $+\%$ fat $+\%$ ash $+\%$ Crude fibre $+\%$ moisture)

\subsubsection{Determination of Crude Fibre ${ }^{(8)}$}

1. About $2 \mathrm{~g}$ of the sample were weighed into a $600 \mathrm{ml}$ long beaker.

2. $200 \mathrm{ml}$ of hot $1.25 \% \mathrm{H} 2 \mathrm{SO} 4$ was added.

3. Beaker was placed on digestion apparatus with preheated plates, boiled, refluxed for 30minutes and filtered through Whiteman GF/A paper by gravity.

4. The beaker was rinsed with distilled water.

5. The residue was washed on the paper with distilled water until the filtrate was neutral. 
6. The residue was transferred from the paper back to the beaker containing $200 \mathrm{ml}$ of hot $1.25 \% \mathrm{NaOH}$.

7. Steps 4 and 5 were repeated.

8. The paper with residue was transferred into a crucible, dried at $100 \mathrm{oC}$ overnight, cooled in a desiccator and reweighed (weight A).

9. The samples were put in furnace at $600 \mathrm{oC}$ for $6 \mathrm{~h}$, cooled in a desiccator and reweighed (weight B).

10. The loss in weight during incineration represents the weight of crude fibre.

$$
\% \text { crude fibre }=\frac{(\text { weight } A)-(\text { weight } B)}{\text { Sample weight }} \times \frac{100}{1}
$$

\subsubsection{Determination of Ash Content ${ }^{(8)}$}

Crucible was washed and dried in an air hot oven, cooled in a desiccator and reweighed. About $2 \mathrm{~g}$ of dried sample were weighed into the empty porcelain crucible previously ignited over a hot plate in the fume cupboard to char organic matter. The crucible was placed in a muffle furnace maintained at a temperature of $600^{\circ} \mathrm{C}$ for $6 \mathrm{~h}$, transferred to a desiccator, cooled and reweighed immediately.

$$
\begin{aligned}
\% \text { Ash }=\frac{\text { (weight of crucible }+ \text { ash) }- \text { wt of empty crucible }}{\text { Sample weight }} \\
\times \frac{100}{1}
\end{aligned}
$$

The sample for the determination of the mineral elements of interest was subjected to acid digestion and subsequently the different elements were determined using appropriate methods.

\subsection{Digestion}

$10 \mathrm{ml}$ of volume of each sample was dispensed into an evaporation dish and treated with $15 \mathrm{ml}$ of conc. $\mathrm{NHO}_{3}$ The mixture was evaporated to $50 \mathrm{ml}$ on a water bather and transferred quantitatively to a $10 \mathrm{ml}$ standard volume flask. It was made up to volume with deionzed water.

\subsection{Mineral Analysis}

The method described by Ranjiham and Gapal ${ }^{(9)}$ was used to determine iron, zinc, potassium and phosphorus. About $1 \mathrm{~g}$ of each sample was weighed into $100 \mathrm{ml}$ round bottom flask. Five millilitres $(5 \mathrm{ml})$ of perchloric acid was added and heated over electric heater in a fume chamber until the solution became colourless. Each of the solution was made up to $10 \mathrm{ml}$ mark with distilled water and the diluted sample was set aside for further studies. The iron, zinc and calcium were analyzed using absorption spectrophotometric method.

\subsection{Determination of Antinutrients}

\subsubsection{Test for Phytic Acid}

A $2.0 \mathrm{~g}$ of the sample was weighed into a test tube and mixed with $20 \mathrm{ml}$ of distilled water. The resulting solution was boiled for 10 minutes. A few drop of puric-acid was added. A yellowish coloration showed the presence of phytic acid.

\subsubsection{Determination of Tannins}

A $2.0 \mathrm{~g}$ of the sample was weighed and mixed with $10 \mathrm{ml}$ of $2 \mathrm{ml} \mathrm{HCL}$ and vigorously shaked. The content was then added to a volumetric flask and made up to $50 \mathrm{mls}$ with water and filtered. $0.5 \mathrm{mls}$ of the filtrate was pipetted into a test tube containing $3 \mathrm{mls} 0.1$ feels in $0.1 \mathrm{ml} \mathrm{HCL}$ and $3 \mathrm{mls}$ of $0.008 \mathrm{~m}$ potassium ferrocyanide $\left(\mathrm{K}_{3} \mathrm{Fe}(\mathrm{CN} 1)_{6}\right)$. The absorbance was read at $720 \mathrm{~m}$. A standard curve was plotted and used for the calculation of the concentration of tannin in the sample.

$$
\text { Tannin Concentration }=\frac{\mathrm{X} \times \mathrm{Df} \times 100}{\mathrm{mg} / 100 \mathrm{~g}}
$$

Where $\mathrm{Df}=$ Dilution factor

$$
\mathrm{X}=\text { Reading form the curve }
$$

\subsection{Sensory Evaluation}

The acceptability tests of the roasted and the cooked breadfruit samples were done using 20 member panelists selected from students of Imo State University Owerri. The students were properly intimated on how to carry out the tests. The samples were evaluated for such characteristics as colour, tests, texture, flavour and "general acceptability. A nine-point hedonic scale as described by Ihekoronye and Ngoddy ${ }^{(10)}$ was used. In the questionnaires distributed to the panelists, they were instructed to score 9 for a parameter extremely liked and 1 for disliked extremely.

\section{Results}

Table 1. The Proximate Composition Of Cooked, Roasted And Raw African Breadfruit Samples

\begin{tabular}{llllll}
\hline Samples & $\begin{array}{l}\text { Protein } \\
(\%)\end{array}$ & Fat (\%) & CHO (\%) & Ash (\%) & $\begin{array}{l}\text { Fiber } \\
(\%)\end{array}$ \\
\hline $\mathrm{A}$ & $23.52 \pm 0.17$ & $11.95 \pm 0.7$ & $58.83 \pm 0.14$ & $1.40 \pm 0.14$ & $4.30 \pm 0.14$ \\
$\mathrm{~B}_{1}$ & $16.25 \pm 0.07$ & $12.05 \pm 0.7$ & $59.45 \pm 0.07$ & $6.55 \pm 0.07$ & $5.70 \pm 0.14$ \\
$\mathrm{~B}_{2}$ & $18.03 \pm 0.11$ & $12.05 \pm 0.07$ & $58.70 \pm 0.30$ & $10.90 \pm 0.14$ & $0.32 \pm 0.40$ \\
$\mathrm{C}$ & $7.15 \pm 0.35$ & $1.95 \pm 0.07$ & $80.65 \pm 0.10$ & $4.95 \pm 0.07$ & $5.30 \pm 0.14$ \\
$\mathrm{D}$ & $19.73 \pm 0.67$ & $9.90 \pm 0.14$ & $62.67 \pm 0.14$ & $3.00 \pm 0.14$ & $4.70 \pm 0.14$ \\
$\mathrm{E}$ & $3.45 \pm 0.07$ & $13.90 \pm 0.14$ & $74.04 \pm 0.14$ & $0.35 \pm 0.25$ & $8.26 \pm 0.20$ \\
\hline
\end{tabular}

Mean of duplicate determination \pm standard deviation, Key: A $=$ Roasted Breadfruit, B1 = Cooked breadfruits, B2 = Water from the cooked Breadfruit, $\mathrm{C}=$ Cooked with corn, $\mathrm{D}=$ Dried Raw dehulled and $\mathrm{E}=$ Raw undehulled $\%=$ Percentage, $\mathrm{CHO}=$ Carbohydrate.

\subsection{Protein}

Protein was highest in roasted breadfruit $(23.52 \pm 0.07)$ and lowest in raw undehulled breadfruit $(3.45 \pm 0.07)$.

\subsection{Fat}

Fat was high in cooked breadfruit sample (12.05 \pm 0.07$)$ and the water from the cooked breadfruit $(12.05 \pm 0.07)$. Fat was lowest in breadfruit cooked with corn $(1.95 \pm 0.07)$. 
However, it was highest in the raw undehulled breadfruit $(13.90 \pm 0.14)$.

\subsection{Ash}

Ash was highest in sample $\left(\mathrm{B}_{2}\right)$ water from the cooked breadfruit $(10.90 \% \pm 0.14)$ and lowest in sample $(\mathrm{E})$ raw undehulled $(0.35 \pm 0.25)$. Ash was also low in sample (A) roasted breadfruit $(1.40 \% \pm 0.14)$.

\subsection{Fiber}

Fiber was highest in raw undehulled breadfruit $(8.25 \pm 0.20)$. It is also high in the cooked breadfruit and least from the water of cooked breadfruit $(0.32 \% \pm 0.40)$.

\subsection{Carbohydrate (CHO)}

$\mathrm{CHO}$ was highest in sample $\mathrm{C}$ (cooked breadfruit with corn), and relatively in all other samples.

Table 2. The Anti-Nutritional Factors in Cooked, Roasted and Raw African Breadfruit

\begin{tabular}{lll}
\hline Sample & Tannin $(\mathbf{M g} / \mathbf{l 0 0 g})$ & Phytate $(\mathbf{m g} / \mathbf{l 0 0 g})$ \\
\hline A & Nil & Nil \\
B $_{1}$ & Nil & Nil \\
$\mathrm{B}_{2}$ & Nil & Nil \\
C & Nil & Nil \\
D & $46.65 \pm 2.90$ & $102.00 \pm 0.85$ \\
E & $38.40 \pm 0.71$ & $70.55 \pm 1.06$ \\
\hline
\end{tabular}

Mean of duplicate determination \pm standard deviation. Key: $A=$ Roasted Breadfruit, $\mathrm{B}_{1}=$ Cooked breadfruits, $\mathrm{B}_{2}=$ Water from the cooked Breadfruit, $\mathrm{C}=$ Cooked with corn, $\mathrm{D}=$ Dried Raw dehulled, and, $\mathrm{E}=$ Raw undehulled

\subsection{Tannin and Phytate}

Tannin was $(46.65 \mathrm{mg} / 100 \pm 2.96)$ and $(38.40 \mathrm{mg} / 100 \mathrm{~g} \pm$ $0.71)$ in dried raw dehulled and raw undehulled breadfruit respectively. Phytate was $(102.00 \mathrm{mg} / 100 \mathrm{~g} \pm 0.85)$ and $(70.55 \mathrm{mg} / 100 \mathrm{~g} \pm 1.06)$ in dried raw dehulled and raw undehulled breadfruit samples respectively.

Table 3. The Mineral Content of Cooked, Roasted and Raw African Breadfruit

\begin{tabular}{lllll}
\hline Samples & Fe (mg/100g) & Zn (mg/100g) & P (mg/100g) & K (mg/100g) \\
\hline $\mathrm{A}$ & $1.55 \pm 0.07$ & $7.25 \pm 0.50$ & $41.15 \pm 0.64$ & $9.00 \pm 0.14$ \\
$\mathrm{~B}_{1}$ & $1.10 \pm 0.01$ & $7.10 \pm 0.42$ & $39.15 \pm 0.64$ & $7.25 \pm 0.50$ \\
$\mathrm{~B}_{2}$ & $2.05 \pm 0.07$ & $10.00 \pm 1.27$ & $42.00 \pm 0.57$ & $21.70 \pm 0.14$ \\
$\mathrm{C}$ & $1.205 \pm 0.28$ & $5.90 \pm 0.71$ & $13.25 \pm 0.50$ & $6.90 \pm 0.57$ \\
$\mathrm{D}$ & $1.55 \pm 0.07$ & $9.05 \pm 0.78$ & $17.05 \pm 1.20$ & $16.15 \pm 1.06$ \\
$\mathrm{E}$ & $1.85 \pm 0.07$ & $3.15 \pm 0.035$ & $6.90 \pm 0.28$ & $12.90 \pm 0.28$ \\
\hline
\end{tabular}

Mean of duplicate determination \pm standard deviation. Key: $\mathrm{A}=$ Roasted Breadfruit, $\mathrm{B}_{1}=$ Cooked breadfruits, $\mathrm{B}_{2}=$ Water from the cooked Breadfruit, $\mathrm{C}=$ Cooked with corn, $\mathrm{D}=$ Dried Raw dehulled and $\mathrm{E}=$ Raw undehulled, $\mathrm{Fe}=$ Iron, $\mathrm{Zn}=$ Zinc, $\mathrm{P}=$ Phosphorus, $\mathrm{K}=$ Potassium

\subsection{Iron}

Sample $\left(\mathrm{B}_{2}\right)$ water from the cooked breadfruit was highest in iron $(2.05 \mathrm{mg} / 100 \pm 0.14)$, sample $\mathrm{B}_{1}$ contained the least iron $(1.10 \pm 0.01)$.

\subsection{Zinc}

Zinc was highest in sample $\left(\mathrm{B}_{2}\right)$ water from the cooked breadfruit $(10.00 \mathrm{mg} / 100 \mathrm{~g} \pm 1.27)$ and lowest in the raw undehulled sample $(3.15 \mathrm{mg} / 100 \mathrm{~g} \pm 0.35)$.

\subsection{Phosphorus}

Phosphorus was highest in sample $\left(\mathrm{B}_{2}\right)$ water from the cooked breadfruit $(42.00 \mathrm{mg} / 100 \mathrm{~g} \pm 0.57)$ and lowest in raw undehulled sample $(6.90 \mathrm{mg} / 100 \mathrm{~g} \pm 0.28)$.

\subsection{Potassium}

Potassium was highest in sample $\left(\mathrm{B}_{2}\right)$ water from the cooked breadfruit $(21.70 \mathrm{mg} / 100 \mathrm{~g} \pm 0.14)$ and lowest in

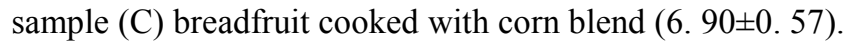

Table 4. The Sensory Properties of Cooked, Roasted and Raw Breadfruit

\begin{tabular}{lllll}
\hline Samples & Colour & Flavour & Texture & $\begin{array}{l}\text { General } \\
\text { Acceptability }\end{array}$ \\
\hline $\mathrm{A}$ & $8.25 \pm 0.917$ & $8.10 \pm 0.97$ & $7.65 \pm 1.98$ & $8.10 \pm 1.68$ \\
$\mathrm{~B}_{1} / \mathrm{B}_{2}$ & $7.25 \pm 1.33$ & $7.25 \pm 1.16$ & $7.45 \pm 1.43$ & $7.25 \pm 1.74$ \\
$\mathrm{C}$ & $7.90 \pm 1.25$ & $7.50 \pm 1.32$ & $7.45 \pm 1.43$ & $8.15 \pm 0.93$ \\
$\mathrm{LSD}(0.05 \%)$ & 0.75 & 0.73 & 1.00 & 0.95 \\
\hline
\end{tabular}

Table 4 shows the effect of roasting cooking and cooking on the sensory evaluation of African breadfruit.

\subsection{Colour}

Colour most acceptable in sample A (roasted breadfruit) and least acceptable in sample $\mathrm{B}_{1} / \mathrm{B}_{2}$ (the cooked breadfruit and the water sieved from it). The colour rating of the 3 samples were not significantly different $(\mathrm{P}>0.05)$. However, the colours of the samples were all acceptable from the result by the panelists.

\subsection{Flavour}

Flavour was most acceptable in sample A but not significantly different $(\mathrm{P}>0.05)$ from that of sample $\mathrm{C}$. All the samples were acceptable by the panelist in terms of flavour.

\subsection{Texture}

Texture shows that sample $\mathrm{C}$ was most acceptable to the panelist while sample $\mathrm{B}_{1} / \mathrm{B}_{2}$ was least acceptable. However, there was no significant difference $(\mathrm{P}>0.05)$ in the texture of the samples and all samples were acceptable in terms of texture.

\subsection{General Acceptability}

General acceptability shows that sample $\mathrm{C}$ was most generally acceptable by the panelists whereas sample $B_{1} / B_{2}$ was the least acceptable. However, there was no significant difference $(P>0.05)$ in the general acceptability of the samples and all were generally acceptable to the panelists. 


\section{Discussion}

\subsection{Proximate Composition of Cooked, Roasted and Raw African Breadfruit}

Table 1 showed the proximate composition of processed African breadfruit samples. Protein was highest in roasted breadfruit $(23.52 \pm 0.07)$ and lowest in raw undehulled breadfruit $(3.45+0.07)$. High protein content in roasted and dried raw dehulled breadfruit samples had negative correlation with the moisture content. This means that decrease in moisture caused increase in protein content of African breadfruit. Protein content in the raw undehulled breadfruit and that cooked with corn was within the values reported by Akachukwu ${ }^{(11)}$ which was $17 \%$. However, protein content in roasted breadfruit was appreciably higher than the value reported. The protein content of breadfruit cooked with corn was low and this may be as a result of starchy nature of the added corn. The very low protein in the raw undehulled breadfruit confirms the report made by Nwokolo ${ }^{(6)}$ and Ejiofor et al, ${ }^{(1)}$ that the brand and pulp had protein content ranging from $5.72-9.40 \%$.

Fat was highest in raw undehulled breadfruit $(13.90 \pm 0.14)$ and lowest in breadfruit cooked with corn $(1.95 \pm 0.06)$. Except for low fat content in the breadfruit cooked with corn, other breadfruit samples showed values within $10.27 \%$ as reported by Ejiofor et al, ${ }^{(1)}$. Lower fat content in breadfruit cooked with corn may be as a result of low fat content in corn because corn is mainly a starch food.

Ash was highest in water sample from the cooked breadfruit $(10.90 \pm 0.14)$ and lowest in raw undehulled. $(0.35 \pm 0.25)$ Ash content gives an idea of the amount of total mineral content of the food material ${ }^{(12)}$. Ash content of the breadfruit samples were within the range reported by Adewusi et al. ${ }^{(13)}$ and Amusa et al. ${ }^{(14)}$ which was between $3.91-0.32 \%$.

Fiber was highest undehulled breadfruit $(8.26 \pm 0.20)$. It was also high in the breadfruit cooked with corn and the raw undehulled samples. Fiber was lowest in water samples from cooked breadfruit $(0.32 \pm 0.4)$. High fiber content in the breadfruit sample may be attributed to the processing method employed.

Carbohydrate was highest in cooked breadfruit with corn $(80.65 \pm 0.14)$ which could be as a result of the addition of corn. The carbohydrate value of the other samples was relatively higher than $40 \%$ as reported by Akachukwu ${ }^{(11)}$.

\subsection{Anti-Nutritional Factors of Cooked, Roasted and Raw African Breadfruit}

Table 2 showed the anti-nutritional factors in processed African breadfruit. Tannin and phytate were not detected in roasted breadfruit, cooked breadfruit and the water, and breadfruit cooked with corn. This shows that processing by roasting and cooking is suitable in eliminating tannin and phytate in breadfruit. However, application of heat in breadfruit processing should be controlled to avoid loss of nutrient. Giami et al. ${ }^{(15)}$ reported that the complete removal of antinutrients requires a more sever heat treatment which in turn reduces the nutritional value and availability of protein as demonstrated by low values obtained for in vitro protein digestibility, protein factor and extractability.

\subsection{Mineral Contents of Cooked, Roasted and Raw African Breadfruit}

Iron was highest in water sample from cooked breadfruit $(10.00 \mathrm{mg} / 100 \mathrm{~g} \pm 1.27)$ and lowest in raw undehulled breadfruit sample $(1.10 \mathrm{mg} / 100 \mathrm{~m} \pm 0.14)$. Zinc was highest in water sample from cooked breadfruit $(42.00 \mathrm{mg} / 100 \pm$ $0.57)$ and lowest in raw undehulled sample $(6.90 \mathrm{mh} / 100 \mathrm{~g} \pm$ 0.28 ). Potassium was highest in water sample from cooked breadfruit $(21.70 \mathrm{mg} / 100 \mathrm{~g} \pm 0.14)$ and lowest in breadfruit cooked with corn $(6.90 \pm 0.57)$. The reason for the high nutrient content in water sample from cooked breadfruit could be because most of the nutrient in the cooked breadfruit must have leached out into the water, and it could be said that the nutrient content of breadfruit is bounded when unprocessed and unbounded when processed.

\subsection{Sensory Evaluation of Roasted and Cooked African Breadfruit}

Colour of the roasted sample was most acceptable and least acceptable is the cooked and water sample from the cooked breadfruit. Flavour was most acceptable in roasted breadfruit and least in the cooked and water sample from the cooked breadfruit. Texture shows that the breadfruit cooked with corn sample was most acceptable and least accepted in cooked and water from the cooked breadfruit. General acceptability shows that the breadfruit cooked with corn was most acceptable by the panelists while the cooked breadfruit was least acceptable. However, the sensory evaluation showed that all the samples were acceptable in term of colour, flavour texture and general acceptability.

\section{Conclusion}

The study shows that African breadfruit (Treculia africana) is a valuable food recourse that should be promoted in Nigeria especially in the Northern parts of the country where it is not commonly consumed. Cooking and roasting of African breadfruit improved its nutritional qualities in terms of proximate composition, minerals and reduction in anti-nutritional factors. Food products prepared by cooking and roasting of breadfruit are acceptable in term of sensory properties. This implies that cooking and roasting are good processing techniques in the improvement of the nutritive value of plant foods such as African breadfruit.

Based on this study, it is recommended that cooking and roasting are desirable methods of processing breadfruit for consumption in the rural and urban areas. The high carbohydrate and fat content will serve as a cheap and available source of calories, protein and minerals for 
healthy growth. It will also help to reduce nutrition and food insecurity. Also, nutritional education on the actual nutritional content of African breadfruit should be promoted especially in those areas where African breadfruit is not appreciated especially in the northern parts of the country.

\section{References}

[1] Ejiofor, M.A.N. Obianuju, O.R. and Okafor, J.C. (1988). Diversifying of African breadfruit as food and feeding stuff. International tree crop Journal 5. P .125-134.

[2] Agu, H.O. and Akinjede, F. (2001). The effect of different drying method on the physico chemical quality of African breadfruit. Proceedings of 25th Annual NIFST conference, 5-9, Lagos.

[3] Kabuo, C.O.O. (2001). Extending shelf-life of African breadfruit (Trecudia African) seeds "Ukwa" (180) by solar drying: effect on proximate composition and Organoleptic quality. In proceedings of 25th Annual NIFST conference, 5-9, Lagos.

[4] Iwe, M.O. and Ngoddy, P.O. (2001). Development of mechanical dehulling process of the African breadfruit (Treculla African). Nigeria food Journal Vol. 19, P.8-16.

[5] Nwufor, M.A., and Mba, P.C. (1988). Student on post harvest roots of African breadfruit (Treculia africana). Seeds in Nigeria J. Int. Bio, 24.17-23.

[6] Nwokolo, N. (1987). Nutritional quality of the seeds of African breadfruit (Treculia africana). Tropical science 27:39-47.
[7] Ajiwe, W.E., Okeke, C.A. and Agbo, H.U. (1995). Extraction And utilization of breadfruit seed oil (treculia African). Bio resource Technology, 53. 183-184.

[8] AOAC (1995) "Official method of Analysis" 11th edition. Association of official Analytical chemists. Washington.

[9] Ranjiham, S.K. and Gapal, K. (1980). Wet Chemical digestion of biological materials for mineral analysis. In: Laboratory Manual for Nutrition Research (pp.83-84) New Delhi: Vikas publishing House

[10] Ihekoronye, I.A. and Ngoddy. P.O. (1985). Integrated science and Technology for the tropics. Macmillan publisher 200.

[11] Akachukwu, C.O. (2002): characteristic and local processing of African breadfruit (Treculia African) in south Eastern Nigeria. Proceedings of 26th Annual conference, P.33-34

[12] Onimawo, A.I. and Egbekun, K.M. (1998). Comprehension food science and nutrition-Ambik Press Benin

[13] Adewusi, S.R.A. Orsadere, B.O. and Oke, O. L. (1991): Studies on weaning diet in Nigeria from carbohydrate sources. Cereal chem. 68; P. 165-109.

[14] Amusa, N.A., Kehinde, I.A. and Ashaye, O.A. (2002) Bio Deterioration of breadfruit (Autoharps communist) in Storage and its effects on the nutrient composition African journal of bio technology Vo.1 (2), P.51-60.

[15] Giami, S.Y. Adindu, M. N., Hart, A.D. and Denenu, E.O. (2001). Effect of hart processing on the vitro protein Digestibility and some chemical properties of Africans breadfruit (Treculia African) seeds plant foods for Human Nutrition. Vol. 56; P. 117-126 (10). 